\title{
"Biotecnological War" - A Conceptual And Perceptual Assessment Tool For Teaching Biotechnology And Protein Chemistry For Undergraduate Students In Biological Sciences.
}

Cruz, C. R. C. ${ }^{1}$, Gaeta, H. H. ${ }^{1}$; Ortolan, B. D. ${ }^{1}$, Belchor, M. N. ${ }^{1,2}$, Rodrigues, C. F. B. ${ }^{1,3}$; Toyama, D. O. ${ }^{1,4}$, Toyama, M. H. ${ }^{1}$

${ }^{1}$ UNESP Instituto de Biociências, Campus do Litoral Paulista, Praça Infante Dom Henrique s $/ \mathrm{n}^{\circ}$, Bairro: Parque Bitaru - CEP 11330-900 - São Vicente; ${ }^{2}$ Programa de Pós-Graduação em Alimentos, Nutrição e Saúde, UNIFESP Campus Baixada Santista, Instituto de Saúde e Sociedade, Avenida Ana Costa, 95 - Gonzaga Santos, SP - CEP 11060-001; 'Programa de Pós-Graduação Interunidades em Biotecnologia Universidade de São Paulo (ICB, IB, FMVZ, EP) - Instituto Butantan Instituto de pesquisas tecnológicas, Avenida Prof. Lineu Prestes, 2415 - Edifício ICB - III Cidade Universitária CEP 05508-900, São Paulo, SP; ${ }^{4}$ Pró-Reitoria de PósGraduação, Universidade Brasil, Campus São Paulo - Rua Carolina Fonseca, 584 Itaquera • São Paulo/SP.

INTRODUCTION. "Biotecnological War" board game, a conceptual and perceptual assessment tool for biotechnology and protein chemistry teaching for undergraduate students in biological sciences and related areas. It is a proposal initially conceived as an alternative complementary tool for biochemistry teaching of proteins and peptides, challenging students, aiming to review concepts transmitted in classroom, stimulating diverse student's abilities, such as their creativity, competitiveness and resource management. OBJECTIVES. Correlate biochemistry importance of proteins and peptides with the development of new products. MATERIAL AND METHODS. Firstly, theoretical-practical classes were given with seminars to be presented by the groups, including topics that will be addressed in game. Groups of 5 students, with previously viewed themes drawn a goal to be achieved. There are two drawn goals variations: Academic or Commercial. Board is divided into provinces, which must be bought with an initial resource to complete the goal. Before the beginning each group will have 15 minutes to plan their actions. The objective is to develop the entire objective drawn with appropriate methodology, having at least 1 territory in each province. RESULTS. This game proved to be an excellent tool for complementary evaluation of students, which stimulated teamwork and a strong competitive spirit within classroom, which allowed to analyze students' perception regarding the protein subject and team work. On the other hand, for teacher and students participating in compulsory traineeship program this game demonstrated new ways to approach complex subjects in biochemistry using creativity with the development of new activities such as this board game. CONCLUSION: Overall, students had a good impression of "Biotecnological war" game since it helped to secure and administer the protein and peptides biochemical subject in a competitive and team work way.

Key words: didactic game, review, protein chemistry, biotechnology. 